\title{
PENERAPAN APLIKASI REKAM MEDIS PASIEN POLIKLINIK RUMAH SAKIT GIGI MULUT GUSTI HASAN AMAN ( RSGM ) BANJARMASIN
}

\author{
Agus Alim Muin ${ }^{1)}$ \\ ${ }^{1}$ Fakultas Teknologi Informasi, Universitas Islam Kalimantan Muhammad Arsyad Al Banjari Banjarmasin \\ Email : alim.blues@gmail.com
}

\begin{abstract}
Abstrack
Kemajuan teknologi jaringan komputer merupakan salah satu pendukung pengolahan data dan informasi yang telah menjadi kebutuhan pokok. Perusahaan industri dan jasa serta semua sektor ekonomi yang ada saat ini telah memanfaatkan jaringan komputer sebagai alat penunjang pengolahan data dan sistem informasi perusahaan. Penelitian ini memberikan solusi bagi permasalahan pada Rumah Sakit Gigi Mulut Gusti Hasan Aman (RSGM) Banjarmasin sebagai salah satu bidang kesehatan yang membutuhkan penggunaan komputer sebagai sarana pengolahan data, sarana penyajian informasi, serta sarana kegiatan. Semua ini dapat dipecahkan dengan menerapkan suatu program aplikasi yang dapat mengintegrasikan semua data pada Rumah Sakit Gigi Mulut Gusti Hasan Aman (RSGM) Banjarmasin dalam satu basis data. Aplikasi yang dibuat bekerja dengan menggunakan php dan mysql sehingga mempermudah pemakai dalam pengolahan data. Dengan menggunakan aplikasi tersebut diharapkan dapat meminimalisir permasalahan-permasalahan pada Rumah Sakit Gigi Mulut Gusti Hasan Aman (RSGM) Banjarmasin seperti penginputan data bermasalah ataupun hilang.Dari permasalahan tersebut memunculkan gagasan untuk membuat sebuah aplikasi yang dapat mempermudah administrasi pelayanan dalam mengisi data pasien baik dalam hal pelayanan dan juga dapat membantu para pegawai mudah mengolah data dan melihat data. Aplikasi ini dikembangankan dengan menggunakan Sublime Text, Xampp dan MySQL sebagai database.
\end{abstract}

Keyword: Administrasi,Aplikasi,Rekam Medik,Web

\section{PENDAHULUAN}

Aplikasi berbasis komputer merupakan suatu alat yang dapat menunjang dalam me laksanakan suatu kegiatan. Penerapan aplikasi diberbagai bidang merupakan suatu keharusan,karena hal tersebutlah orang lebih mengutamakan pemecahan masalah yang lebih cepat dan akurat Dengan digunakannya aplikasi sebagai solusi tercepat dan akurat. Salah satu pengolahan data kantor yang menggunakan aplikasi komputerisasi adalah pengolahan data informasi mengenai pelayanan pada instansi.

Rumah Sakit Gigi Mulut Gusti Hasan Aman (RSGM) Banjarmasin adalah salah satu instansi daerah.Sedangkan untuk aplikasi pelayanan administrasi Rekan Medis Pendaftaran Poliklinik ini masih secara manual dikarenakan di instansi ini memiliki kurang dari 10 pegawai pada bagian administrasi pelayanan pendaftaran pasien. Pada Rumah Sakit Gigi Mulut Gusti Hasan Aman (RSGM) Banjarmasin meskipun sudah memiliki aplikasi, penggunaannya masih kurang dimaksimalkan dan perlu dikembangkan. Masih terdapat kendala-kendala yang terjadi,yaitu sering terjadi kekeliruan informasi yang didapatkan dari berbagai sumber data [4]

Sejumlah penelitian yang telah dilakukan dalam membangun "Penerapan Aplikasi Rekam Medis Pasien poliklinik rumah sakit gigi mulut gusti hasan aman (RSGM) banjarmasin" adalah diantaranya "Sitem Informasi Pendaftaran dan Pengolahan Data Pasien Pada Klinik Emerlard Care" oleh Vera Indriyanti tahun 2015 dengan permasalahan Bagaimana Perancangan Sistem Informasi pada klinik diusulkan penulisan menunjang proses pendaftaran dan pengolahan data pasien. [1].

Kemudian pada penelitian Puspita Ningsih Wigurnarti tahun 2014 yang berjudul "Sistem Informasi Pendaftaran dan Pengolahan Data Pasien Pada Drg.Setiawan T Bandung Bebasis Web" memiliki permasalahan Bagaimana implementasi sistem informasi pendaftaran dan pengolahan data pasien pada drg.setiawan kedalam bentuk sistem manual inputan [2].

Selanjutnya ialah berjudul "Pembangunan Aplikasi Siste Informasi Pelayanan Medis dan Pengelolaan Data Pasien Pada Poliklinik Griya 
Chrysalis Bandung berbasis web" oleh Fithri Siti Mardhiyah pada tahun 2014 dengan Bagaimana implementasi sistem pelayanan medis dan pengelolaan data pasien kedalam bentuk sistem yang terhubbung dengan jaringan sehingga mengahsilkan program aplikasi berbasis web yang dapat mengelola dan menyimpan data pasien dan memberikan informasi mengenai pendaftaran beserta rekam medis. [3].

Oleh karena itu, berdasarkan dari permasalahan yang ada pada Rumah Sakit gigi mulut gusti hasan aman (RSGM) Banjarmasin, penulis ingin menganalisa sebuah aplikasi yang mampu mempermudah pelayanan pengimputan data pasien di rumah sakit gigi mulit gusti hasan aman

\section{METODE PENELITIAN}

Teknik pengumpulan data yang akan digunakan pada penelitian ini adalah :

\section{Kepustakaan}

Merupakan pengumpulan data dengan cara pengambilan data-data dari catatan kuliah serta buku-buku dan juga melakukan browsing internet untuk mendapatkan hal yang ada kaitannya dengan desain dan perancangan sistem informasi.

2. Metode Observasi

Metode observasi adalah sistem pengumpulan data dengan cara melakukan pengamatan secara langsung pada objek yang diteliti, sehingga didapat data yang akurat.

3. Wawancara

Melakukan tanya jawab denganpihak tempat penulis melakukan penelitian.

4. Perancangan

Metode Perancangan adalah metode dengan cara merancang dan membuat profil untuk keperluan penyampaian informasi yang berkaitan dengan sistem informasi.

\section{Metode Uji Coba}

Penulis melakukan uji coba dari sistem informasi administrasi yang telah dibuat secara keseluruhan sebelum di implementasikan ditempat penelitian.

6. Metode Implementasi

Pada tahapan ini sistem di
implementasikan secara keseluruhan
sebagai akhir pembangunan perangkat

lunak atau menerapkan uji coba pada obyek.

\section{Rancangan Model Sistem}

Pada rancangan model sistem ini akan membahas gambaran kebutuhan sistem yang akan dibangun. Pemodelan rancangan sistem ini menggunakan UML (Unified Modelling Language) yang memiliki beberapa tahap yaitu use case diagram, activity diagram, sequence diagram, dan class diagram.

\section{Use Case Diagram}

Pada bagian use case diagram akan membahas alur skenario hubungan antara user dan sistem, pada use case diagram ini membahas kebutuhan sistem dari sudut pandang user/pengguna.

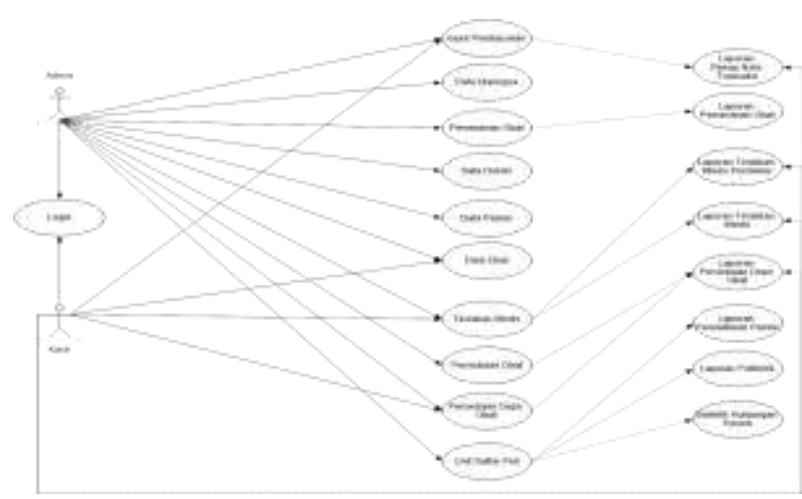

Gambar 1. Use Case Diagram

Activity diagram dari usecase diagram Penerapan Aplikasi Rekam Medis Pasien poliklinik rumah sakit gigi mulut gusti hasan aman (RSGM) banjarmasin adalah sebagai berikut : 


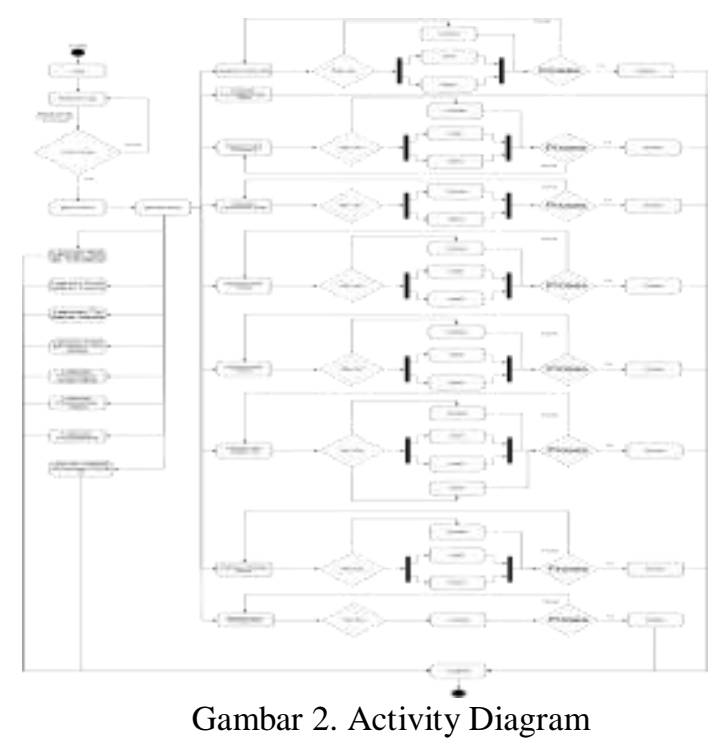

1. Activity Kasir

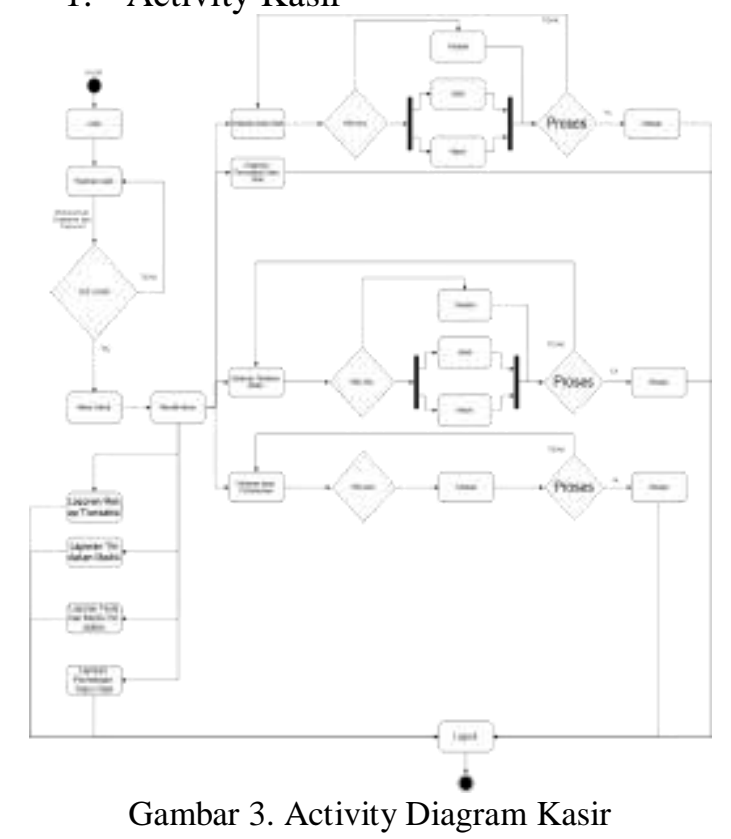

\section{Sequence Diagram}

Sequence diagram merupakan gambaran interaksi antar objek dalam sistem seperti pengguna, tampilan dan sebagainya berupa pengiriman serangkaian data antar objek.

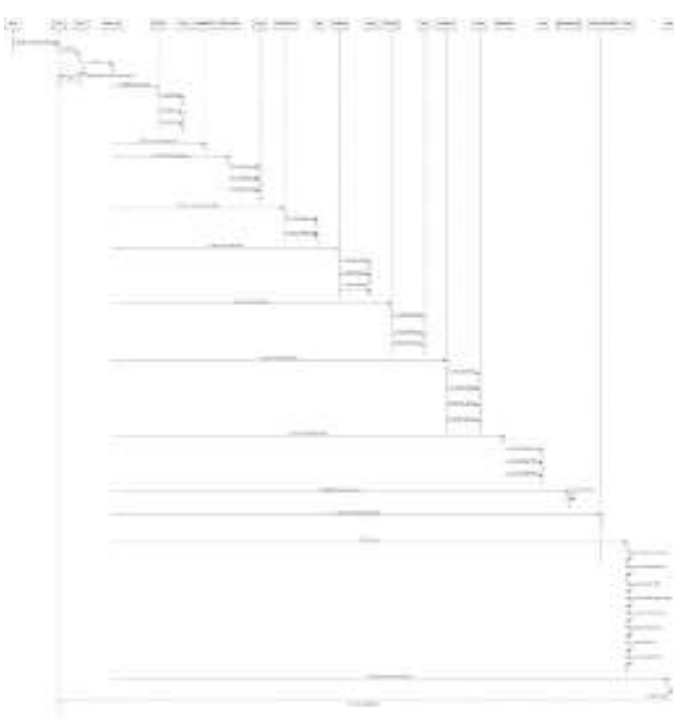

Gambar 4. Sequence Diagram

Class diagram mendeskripsikan jenis-jenis objek dalam sistem dan berbagai macam hubungan statis yang terdapat diantara mereka. Class diagram Penerapan Aplikasi Rekam Medis Pasien poliklinik rumah sakit gigi mulut gusti hasan aman (RSGM) banjarmasin dapat dilihat pada gambar dibawah ini :

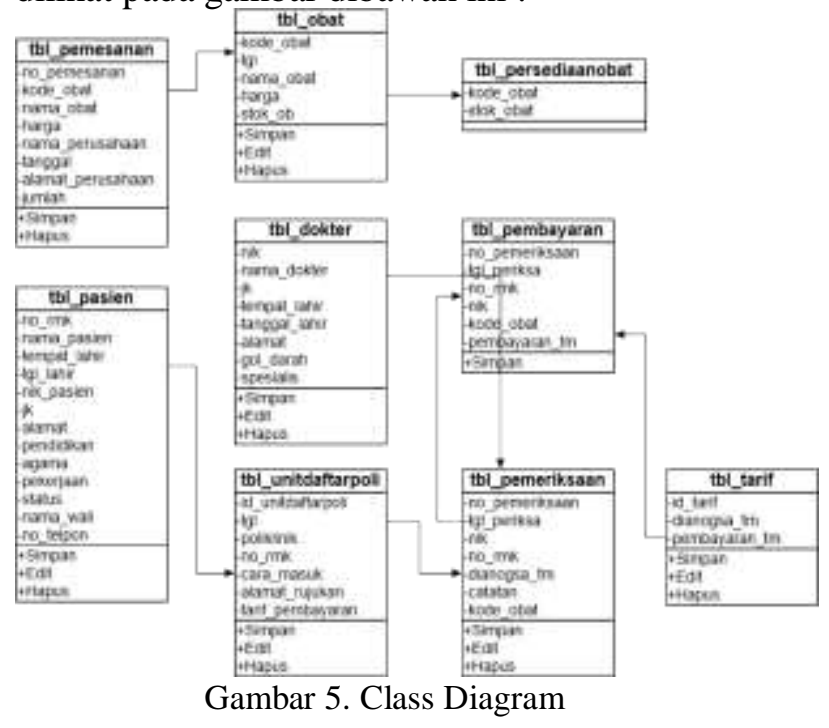

3. HASIL DAN PEMBAHASAN

a. Langkah-langkah Pembuatan Sistem

Langkah dalam pembuatan sistem ini menggunakan metode waterfall. Adapun tahapan yang ada pada metode sebagai berikut :

1) Analisis Kebutuhan/Requirement Analisis

2) Desain Sistem/System Design

3) Impelementasi/Implementation 
4) Integrasi Pengujian/Integration and Testing

5) Operasi dan Pemeliharaan/ Operation and Maintenance

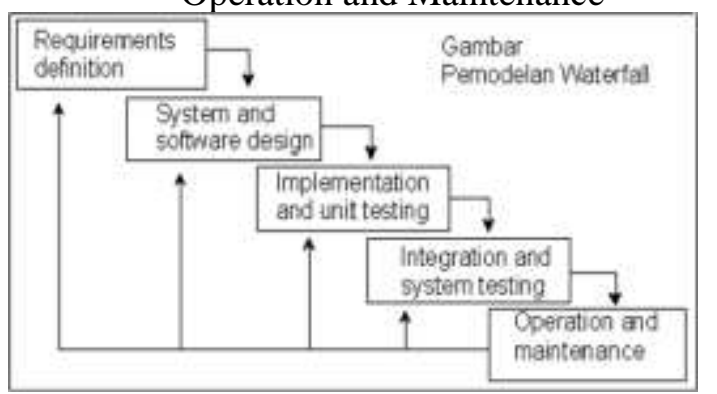

Gambar 6. Metode Waterfall

b. Hasil Tampilan Aplikasi

1) Tampilan Antarmuka Halaman Utama Admin

Tampilan dibawah ini adalah tampilan halaman utama dari admin saat melakukan login.

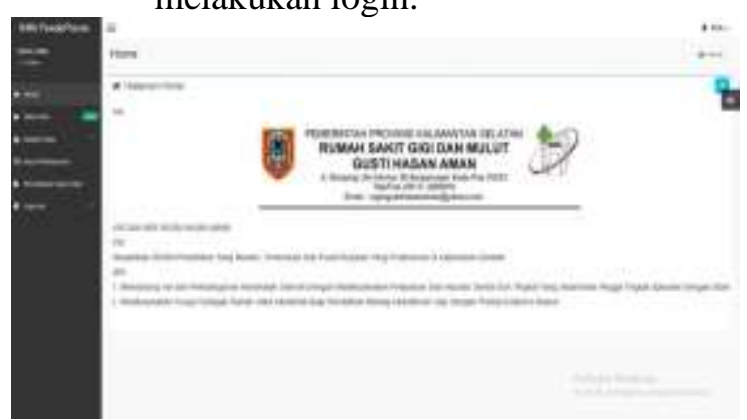

Gambar 7. Tampilan Halaman Utama Admin

2) Tampilan Antarmuka Halaman Tindakan Medis

Tampilan Form Data Tindakan Medis adalah form yang berfungsi untuk menampilkan form tambah data tindakan medis dengan aksi simpan dan batal.

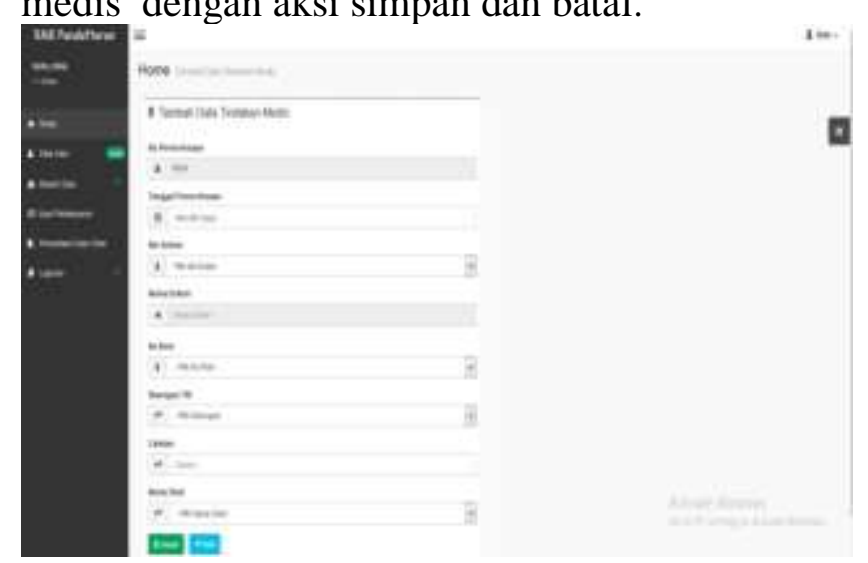

Gambar 8. Tampilan Form Data Tindakan Medis
3) Tampilan Antarmuka Laporan Nota Transaksi

Tampilan Laporan Nota Transaksi Pembayaran berfungsi untuk menampilkan laporan data input pembayran pada saat di klik tombol cetak.

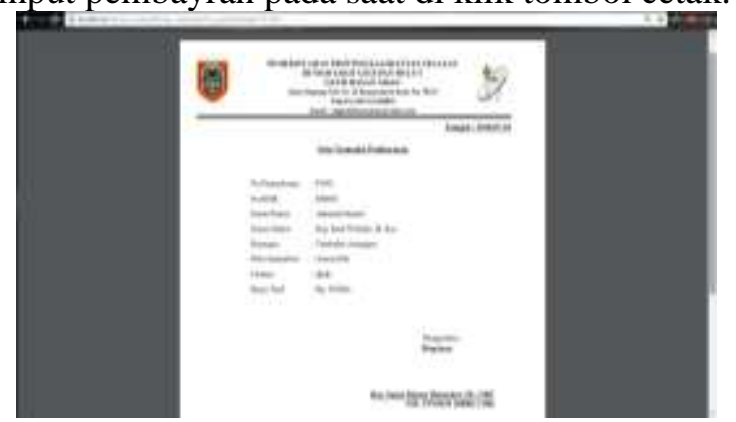

Gambar 9. Tampilan Laporan Nota Transaksi

\section{KESIMPULAN}

Setelah melalui beberapa tahapan dan pembahasan penelitian ini untuk menghasilkan Penerapan Aplikasi Rekam Medis Pasien poliklinik rumah sakit gigi mulut gusti hasan aman (RSGM) banjarmasin, dengan melihat dari semua permasalahan, analisis, perancangan dan pembuatan sistem maka dapat ditarik kesimpulan diantaranya :

1. Aplikasi ini dapat memberikan kemudahan serta mempercepat pengolahan data pada administrasi pelayanan rawat jalan di Rumah Sakit Gigi Mulut Gusti Hasan Aman (RSGM) Banjarmasin.

2. Informasi output data yang di sajikan berupa laporan menjadi lebih akurat dan tingkat ketelitian lebih tinggi, sehingga kemungkinan kesalahan sangat kecil.

3. Dengan adanya aplikasi ini dapat memberikan keamanan dalam penyimpanan data sehingga tidak perlu khawatir data menjadi rusak ataupun hilang.

4. Aplikasi ini memudahkan dalam melakukan perbaikan atau mengoreksi data, apabila suatu waktu terjadi kesalahan dalam menginput data. 


\section{REFERENSI}

[1]Indriyanti.V.(2015).sistem informasi 1pendaftaran dan pengolahan data pasien pada klinik kecantikan emerald beauty care. //elib.unikom.ac.id/files/disk1/670/jbptunikom pp-gdl-veraindriy-33463-1-unikom_v-l.pdf. diakses tanggal 16 februari 2019

[2]Wigunarti.P.(2014).sistem informasi pendaftaran dan pengolahan data pasien pada drg. Setiawan $\mathrm{t}$ bandung berbasis web. //elib.unikom.ac.id/files/disk1/577/jbptunikom pp-gdl-puspitanin-28830-2-unikom_p-r.pdf . diakses tanggal 15 februari 2019

[3] Mardhiyah.F.S.(2014). Pembangunan Aplikasi Sistem Informasi Pelayanan Medis dan Pengelolaan Data Pasien pada Klinik Griya Chrysalis Bandung Berbasis Web.//elib.unikom.ac.id/gdl.php?mod=browse $\& o p=$ read\&id=jbptunikompp-gdl-fithrisiti32105. diakses tanggal 13 februari 2019

[4] Triyotno, A. (2005, Juni 14).

Perancangan Administrasi rekam medis dan Pengertiannya. Retrieved from http://bolu.blogspot.com: http://bolu.blogspot.com/1/2006/pdf/admnegeri.html. diakses tanggal 10 februari 2019 